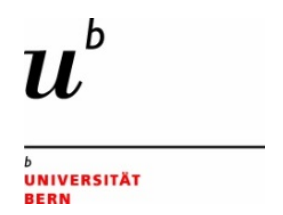

\title{
Impact of Transport Costs on Vietnamese Textile Exports
}

Prof. Dr. Trinh Thi Thu Huong

Foreign Trade University (FTU), Vietnam

ttthuhuong@ftu.edu.vn

Transport cost is a critical component that structure price of goods at destination points in international trade. This research explored and analysed transport cost and its impact on export by investigating the relationship between transport cost and export of textile (a specific sector) in Vietnam (a developing country) from 2012 to 2014.

Research for this paper was funded by the Swiss State Secretariat for Economic Affairs under the SECO / WTI Academic Cooperation Project, based at the World Trade Institute of the University of Bern, Switzerland.

SECO working papers are preliminary documents posted on the WTI website (WWW.Wti.org) and widely circulated to stimulate discussion and critical comment. These papers have not been formally edited. Citations should refer to a "SECO / WTI Academic Cooperation Project" paper with appropriate reference made to the author(s). 


\title{
IMPACT OF TRANSPORT COSTS ON VIETNAMESE TEXTILE EXPORTS
}

\author{
Assoc. Prof. Dr. Trinh Thi Thu Huong, Foreign Trade University \\ Pham Thanh Ha, Foreign Trade University \\ Nguyen Ngoc Lan, BI Norwegian Business School
}

\begin{abstract}
Purpose:

Transport cost is a critical component that structure price of goods at destination points in international trade. This research explored and analysed transport cost and its impact on export by investigating the relationship between transport cost and export of textile (a specific sector) in Vietnam (a developing country) from 2012 to 2014.
\end{abstract}

\section{Methodology:}

The framework for estimation transport cost and its impact on international trade in textile in Vietnam is based on gravity model. The two stage least squares (2 SLS) model in the estimation was used, in which for the first stage, the transport cost is regressed on a set of exogenous variables including five instrumental variables that affect transport cost, but do not affect exports. In the second stage, the forecasted of transport cost enters as one of the regressors of the exports. A survey was conducted for data collection purposes.

\section{Findings}

Results from the paper show that higher distance and poor partner port infrastructure leads to a notable increase in transport costs. Besides, higher importer income, depreciating real exchange rate and better logistics condition facilitate trade growth. In contrast, greater transport costs, distance and tariff significantly deter trade. Based on the research results, the paper provides recommendations and solutions that encompass a series of policies to effectively reduce the transport cost in textile export in Vietnam

\section{Research limitations/implications}

Limitation is related to the information related to freight rates provided by liner shipping as well as airlines agents. Besides, the research ignores the inland transport costs, which might be a great issue in developing country such as Vietnam.

\section{Originality/Value}

Proposed solutions and recommendations can be considered as reliable practical for Vietnamese government in a common effort to reduce transport costs in textile export in particular and in international trade in general.

Keywords: transport cost, textile export, Vietnam, international trade, distance, infrastructure, tariff. 


\section{INTRODUCTION}

Since Vietnam implemented trade reform policies and opened its doors for foreign investors, export of textile products has been in a rapid progress and promises a fruitful future. Over the last decades, average annual growth rate of Vietnam's textile export reached 13.62\% (UN Comtrade), among the fastest growing sector in Asia. Vietnam's textile products have been currently available in 180 countries and territories in the world and five continents from America, Europe to Africa and Asia. According to Vietnam Textile \& Apparel Association, Vietnam is going to reach the third place in the world textile export.

However, the opportunities do not go without challenges. Despite the fact that tariff measures are declining, transport costs and other non-tariff barriers remain an obstacle for Vietnam's export. Plausible explanations for high transport cost in Vietnam are poor infrastructure and inadequate investment in transport modes. Transport costs not only affect the direction of textile export but also influence modal choice and the organization of production, particularly as "just-intime", "made-to-order" or "off-the-rack" methods get extended to the global level. In turn, these new production methods are placing increasing demands on the transport system.

The study of transport cost and its impact on trade is of relevant interest for economists in both developed and developing world. While transport cost varies according to region and time, various researches reach to the same conclusion that it deters foreign trade. This paper differs from former research in the way that it investigates the relationship between transport cost and international trade of textile (a specific sector) in Vietnam (a developing country) from 2012 to 2014, with focus on the year 2013.

The paper studies the impact of transport costs on the volume and price of international trade. To what extent has the rise in international trade been driven by changes in transport costs? Is its magnitude comparable to distance and tariff barriers. What implication can be withdrawn from our country's experience?

The paper is structured into five sections. First, an overview of Vietnamese textile export is presented. The literature review of transport cost and measurement of international trade is then discussed. In the third part, the methodology section explains the data collection and the framework for the paper. The findings from the 
study is further presented and explained. Finally, the recommendations regarding a set of measures for reducing transport cost and expand the international trade of Vietnam are withdrawn.

\section{OVERVIEW OF VIETNAMESE TEXTILE EXPORT}

\section{Export trend}

Figure 1 demonstrates the value of apparel export in Vietnam over an

eleven-year period. Apparel export which accounts for most value of textile export, with its turnover increased gradually from $\$ 4.8$ billion in 2005 to as much as $\$ 19.1$ billion in 2014. With an impressive total turnover of $\$ 135$ billion in eleven years, textile in general and apparel in particular currently stand as the second largest export sector of Vietnam. Its annual growth rate was among the highest in the world, at an average of $16 \%$ per year.

Figure 1: The export value of Vietnam apparel

(billion USD)

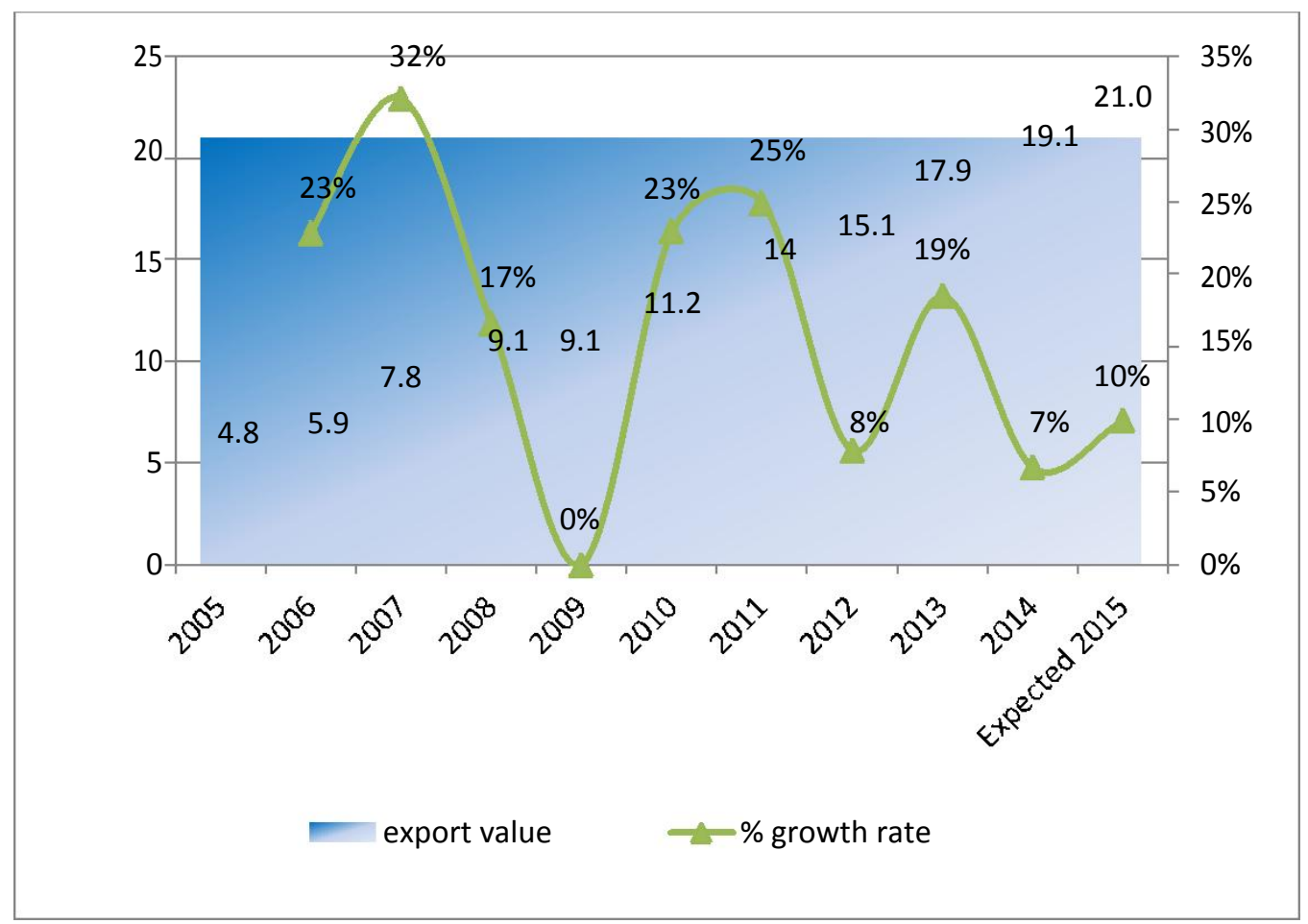

\section{Export products}

Source: UN Comtrade, 2015

Proliferation of Vietnam's textile and garments export in the last few fiscal years is really noticeable. A glance at the figure 2 reveals the exporting data of textile and apparel products of Vietnam in 2012, 2013, and 2014. According to UN Comtrade, most of the exported products had an upside trend in terms of value during the period. 
Figure 2: Categories of apparel products for export in 2012, 2013 and 2014 (\%)

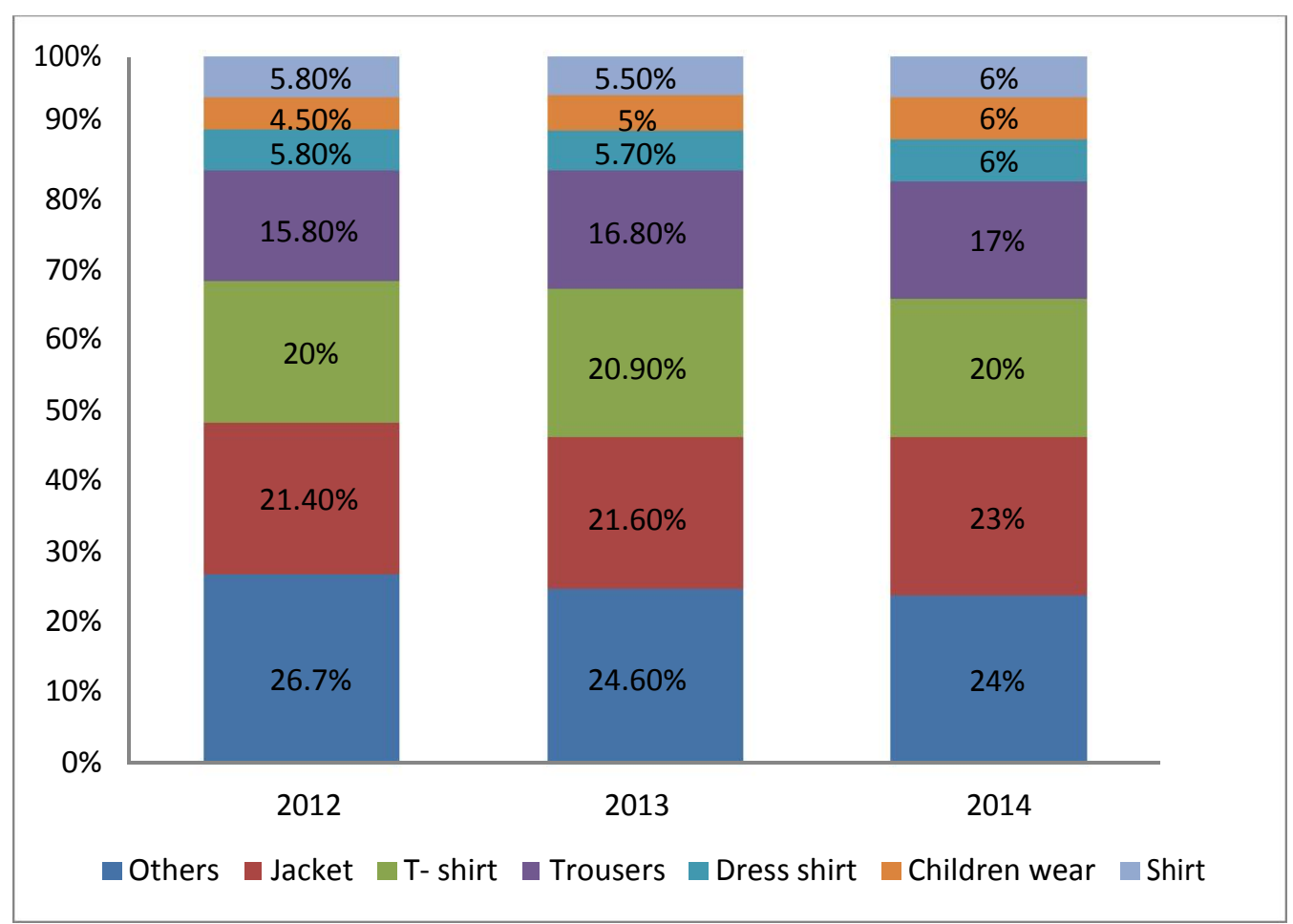

\section{Export markets}

Source: UN Comtrade

Figure 3 shows the international markets for Vietnam’s textile and apparel exports. In 2014, Vietnam's textile and apparel export has been available in 180 international markets with 53 countries and territories investing in Vietnam (General Statistics Office, 2015). So far, Vietnam is getting the biggest cake of the orders leaking out from China, Vietnam. The export figures show that Vietnam is really growing fast especially in an important market like USA. Vietnam has now made a prominent space in the global apparel market and they are expanding their capacity to be ready to cope up with the upcoming opportunities from China and even Bangladesh. After China, Vietnam is now the second largest exporter of readymade garments to the two most influential markets-USA and Japan. 
Figure 3: Export destinations of Vietnam's textile and apparel

(billion USD)

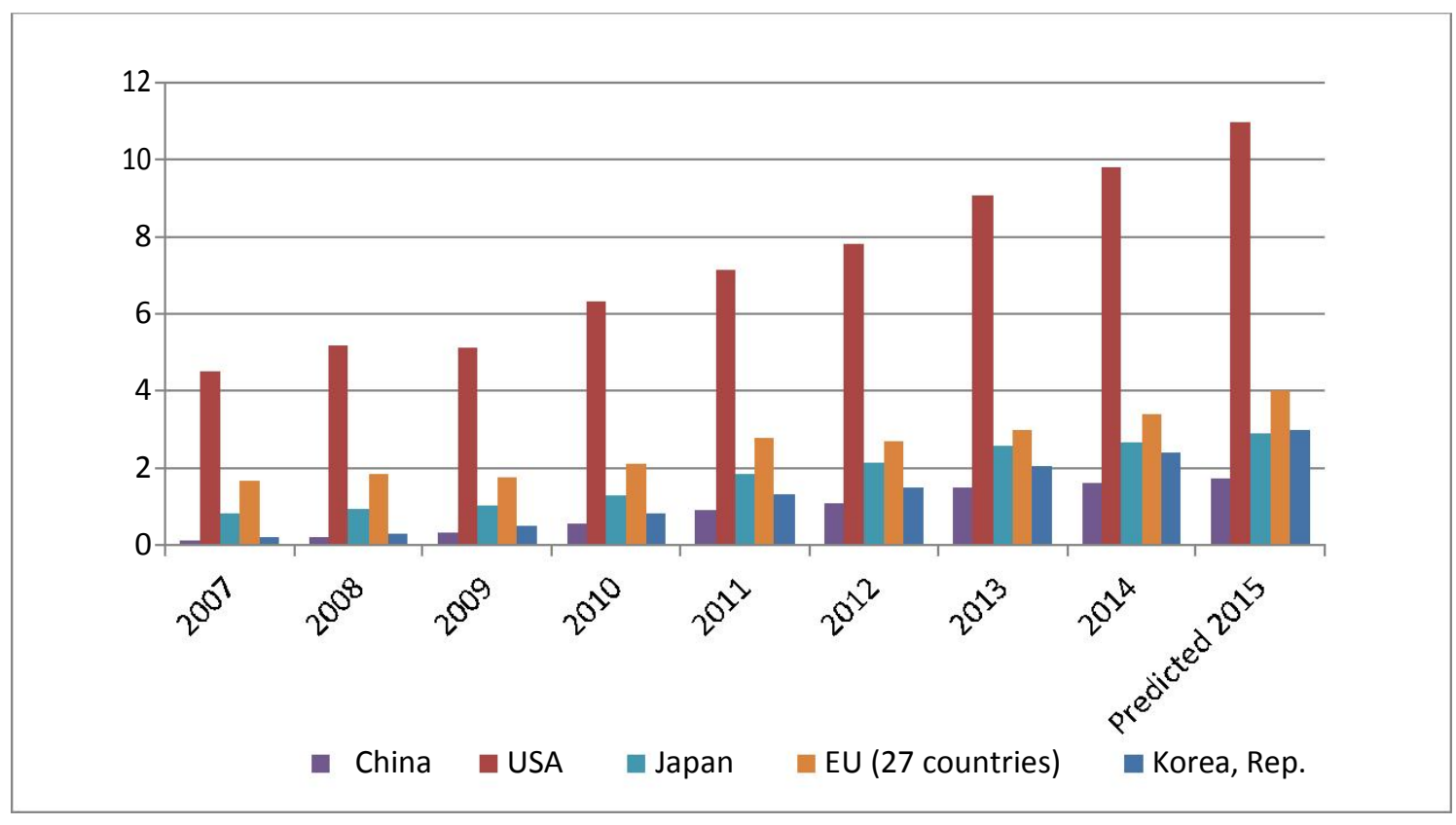

Source: UN Comtrade, 2015

The United States is the largest importer of Vietnamese textile, with the export value in 2014 is 9.8 billion. Vietnam is currently the second largest suppliers of textile to the United States, after China, with the export value to the United States in 2014 accounts for 50\% the total value of the industry. EU is the second consumption of Vietnamese textile, with the export proportion in 2014 accounts for more than $17 \%$ of the industry. Japan is the third largest importer of Vietnamese textile. Japan is famous for their requirement on quality, packing and technical specification. However, in recent years since 2011, the relationship between Vietnam and Japan is becoming fruitful and Japan is more willing to invest FDI in Vietnam, including for textile industry. Korea is the fast track consumer of textile from Vietnam. In 2014, total export from Vietnam to Korea reached \$ 2.4 billion, increased 27\% compared to 2013. 


\section{LITERATURE REVIEW}

\section{Determinants of transport cost}

From the theoretical framework above, we have a function of transport costs as follows:

Transport costs $=\mathrm{f}$ (distance, geography, infrastructure, trade facilitation, technology, fuel cost, mode, delivery time...).

\section{- Distance}

Transport costs rise in distance, as each kilometre travelled requires fuel, manning and capital expense (Portugal, 2008). Distance is the sea distance to the nearest major world market. (Radelet \& Sachs, 1998) ran the model on the determinants of shipping cost (CIF/FOB band, log from 1965 to 1990) and concluded that each $10 \%$ increase in sea distance is associated with a $1.3 \%$ increase in shipping cost.

- Mode

For the mode variable, a strong positive relationship between mode and transport cost as air transport is more costly than sea transport. SAS Cargo noted that air transport were 70\% more costly than sea transport. Martinez (2003) found the significant sign of dummy "mode" when comparing the transport costs of cement by road and ship. If cement was exported by road from Spain, the cost increased $5.19 \%$ compared to its shipment by vessel.

\section{- Infrastructure}

The importer infrastructure variable was added in Limao and Venables (2001)'s model, which showed a statistically significant coefficient with the expected negative sign. More interestingly, the inclusion of infrastructure measures improved the fit of the regression since the adjusted $R_{2}$ changed from 0.2 to 0.31 , which corresponded to the importance of infrastructure in determining transport costs. Martinez (2003) also concluded that an improvement of $1 \%$ in the infrastructure of the destination country lowered transport costs by $0.14 \%$.

- Delivery time

Delivery time impacts not only perishable and agricultural products but also manufactured products. It is a plausible proxy for the quality of transport service. Martinez (2001) obtained a 0.15 percentage value for the estimated coefficient of transit time, meaning a $1 \%$ increase in the delivery time added an extra $0.15 \%$ in 
cost.

- Technology (Increasing Returns to Scale and Containers)

The appearance of containerized transport has been an evolution in transport sector during the last decade. Containers do not only improve the volume of trade but also change the nature of trade. Since the development of containerization, Levinson quoted that "If ever there was a business in which economies of scale mattered, container shipping was it”.

- Continent, Adjutancy and Language

In a model of Martinez (2003), the dummy variables, proxy for certain geographical and cultural characteristics, namely, being neighbours, being an island, being landlocked or sharing a language was not significant. A possible interpretation is that they do not represent direct trade costs. Alternatively, they may indicate cultural similarities, preferences or production effects, which in turn, better trade relation.

\section{Gravity model}

The paper relies on a classical theoretical framework to assess the relative importance of transport costs on trade: the gravity model, which becomes the workhorse of international trade. The gravity model was first introduced by Jan Tinbergen (1962), based on the Newtonian theory of gravitation. Tinbergen explained the bilateral trade flow between two countries as the way planets were mutually attracted to each other in proportion to their sizes and proximity. Countries which were similar in GDPs and proximity to their partners were more likely to trade.

Before Tinbergen (1962), Ravenstein (1885) and Zipf (1946) used gravity concepts to model migration flows, but Tinbergen was the first person to develop a gravity equation, which has been improved time by time, to analyse trade between countries. In Tinbergen's version, the gravity model was presented as an intuitive ways of understanding trade flows:

$$
X_{i j}=S_{i} M_{j} w_{i j}
$$

where $\mathrm{X}_{\mathrm{ij}}$ is the monetary value of exports from $\mathrm{i}$ to $\mathrm{j}$; $\mathrm{S}_{\mathrm{i}}$ denotes exporterspecific factors (such as exporter's GDP and population); $\mathrm{M}_{\mathrm{j}}$ represents the factors that affect import demand (importer's characteristics, such as GDP and population); 
G comprises all factors that do not depend on country i and $\mathrm{j}$, such as the level of globalization. Finally, $\mathrm{w}_{\mathrm{ij}}$ is the trade cost between two nations, including tariff and transport cost.

\section{- $\quad$ Transport Costs and Trade}

It is obvious that transport cost as an adverse impact on international trade. However, it is intriguing to capture the size of the proxies and the size of the barriers. Hummel $(1999,2001)$ ran a model with the freight and tariff variables as an explanation for the value of bilateral imports, summed over all goods, for all country pairs with positive values for trade. The average elasticity of freight and tariff for 62 2-digit "goods" were 5.6, implying that a 10\% tariff and freight increase lowers trade by 56 percent and mark-ups on the order of 22 percent. In addition, rather than being exported with high transport cost, heavy weighted goods such as cork, wood, paper, rubber manufactures and inorganic chemicals were produced at the locations where there was a high demand.

Limao and Venables (2001) estimated elasticity of transport cost and trade volume on distance and infrastructure. The paper did not only prove that the point estimates of trade towards transport costs were -6.47 base on distance and less than -2 base on partner infrastructure measures and border but also reflected the economies of scale through which higher volumes lead to lower costs of transport.

In contrary to Hummel (1999, 2001), Limao and Venables (2001), Baier and Bergstrand (2001) concluded that reduction in trade costs played a minor path in trade growth. With the data of 16 OECD countries from UN Comtrade in the period 1958-60 and 1986-88, his result showed that trade growth was explained 66\% by income, $26 \%$ by trade liberalization and only $8 \%$ by lower transport costs. The possible reason for his apparent contradiction to previous study is that the crosssection variation in freight rates in his sample is quite large, while transport costs did not fall very much over time.

\section{METHODOLOGY}

\section{Model specification}

Traditionally, the multiplicative gravity model has been linearized and estimated using OLS assuming that the variance of the error is constant across observations (homoscedasticity), or using panel techniques assuming that the error is constant across countries or country-pairs. 
We use the two stage least squares (2 SLS) model in the estimation. In the first stage of 2SLS, the transport cost is regressed on a set of exogenous variables including five instrumental variables that affect transport cost, but do not affect exports. In the second stage, the forecasted of transport cost enters as one of the regressors of the exports.

There are two reasons why the 2 SLS is justifiable. Firstly, transport cost is considered an endogenous variable in the export regression and instrumental variables are needed to correct for endogeneity using two-stage estimation procedure. Secondly, the error term in the export regression contains unobserved country-specific effects so that the error term may be correlated with the variations in some of the regression. For example, shocks in the Gross Domestic Product (GDP) may be highly correlated with the shocks that affect export. The tests for endogeneity, the test for over-identification, and the test for strength of instruments 
are conducted to ensure the robustness of the coefficients, of which the results are all in favour of 2 SLS.

The first equation in the 2 SLS is:

$$
\begin{gathered}
\operatorname{lnTC}_{\mathrm{j}}=\beta_{0}+\beta_{1} \operatorname{lnDays}_{\mathrm{j}}+\beta_{2} \operatorname{lnInfr}_{\mathrm{j}}+\beta_{3} \text { Mode }+\beta_{4}\left(\text { Infr*Mode }^{*}+\beta_{5} \operatorname{lnDist}_{\mathrm{j}}\right. \\
+\beta_{6}\left(\text { Dist }_{\mathrm{j}} \text { Mode }+\varepsilon_{\mathrm{i}}\right.
\end{gathered}
$$

The endogenous variable Transport Cost $\left(\mathrm{TC}_{\mathrm{j}}\right)$ is measured by distance $\left(\mathrm{D}_{\mathrm{j}}\right)$, delivery time (Days), airport and seaports $^{\text {ee }}$ infrastructure $\left(\operatorname{Infr}_{j}\right)$ and means of transportation (Mode).

The second-stage equation of the 2SLS is:

$$
\begin{gathered}
\ln \mathrm{X}_{\mathrm{j}}=\gamma_{0}+\gamma_{1} \ln \mathrm{Y}_{\mathrm{j}}+\gamma_{2} \operatorname{lnDist}_{\mathrm{j}}+\gamma_{3} \text { InFTC }+\gamma_{4} \mathrm{POP}_{\mathrm{j}}+\gamma_{5} \text { RER }+\gamma_{6} \text { Infr }+\gamma_{7} \text { Tariff }+\gamma_{8} \\
\text { ASEAN }+\gamma_{9} \mathrm{TPP}+\gamma_{10} \text { Comcont }+\mu_{\mathrm{j}}
\end{gathered}
$$

where Ln denotes natural logarithms, $X_{j}$ is the export values of textile and apparels from Vietnam to country j. $Y_{j}$ is income in the destination market, FTC is forecasted transport costs, Infr is the infrastructure level of importing country, $P O P_{j}$ is the number of population in importing country, $R E R$ is the real exchange rate,

Tariff is the import tariff of textile in the importing country, ASEAN is a dummy variable which equal to 1 if the importing country is a member of ASEAN and 0 otherwise, TPP is a dummy for TPP countries, Comcont takes value of 1 when countries share the same continent. ASEAN in this paper refers to nine official nations, including Brunei, Cambodia, Indonesia, Laos, Malaysia, Myanmar, the Philippines, Singapore, and Thailand. Meanwhile, ten TPP countries (trading partner of Vietnam) are Australia, Brunei, Canada, Chile, Japan, Malaysia, Mexico, New Zealand, Peru, Singapore and the United States. All the variables except dummies are in natural logs. $\mu_{j}$ denotes the error term that is assumed to be independently normally distributed.

On the purpose of the study, the null hypothesizes are:

$\mathrm{H}_{0}$ : Transport Cost has no impact on Export

$\mathrm{H}_{1}$ : Transport Cost has a negative impact on Export

\section{Data}

\section{Of the first stage}

Our analysis is based on cross-section annual data in 2013 covering export flow of Vietnam and 274 destinations. Primary data on transport costs obtained from quotation of shipping lines and their agents. A total of 89 surveys were sent 
and 76 were received, 49 of which from shipping agents and the rest 27 from airline agents. The data comprises transport price from Cat Lai, Vietnam to 274 destination terminals and ports.

The variables studied are identified as follows:

- Transport Cost

Through an extended interview with logistics staff in various companies, we collect the ocean and air transport cost (freight + surcharges) for the textile shipments. The data is mainly constructed based on the quotations of famous shipping lines such as Waiha, Hanjin, KeeLine and SITC.

Surcharges at departure+ FCL/LCL Freight+ Surcharges at destination $=$ Constant

Similar to sea transport cost, we collect air freight and surcharge from various sources through both formal and informal interview and email with airlines, freight forwarders and their agents.

- Distance

The sea distance in kilometre is taken from Searates website, assessed on 25 December, 2015. The chosen port of departure is Cat Lai, District 2, Ho Chi Minh City as the port is responsible for over $80 \%$ of Vietnamese exports. Also the interview with logistic staff confirms the importance of Cat Lai Port to Vietnam textile exports. The database includes information on the distance from Cat Lai, Ho Chi Minh City to main ports in other countries.

\section{- Infrastructure}

The sea port infrastructure is taken from World Bank Database for the year 2013 and 2014. The quality of port infrastructure is scored from 1 to 7 (1= extremely underdeveloped to $7=$ well developed and efficient by international standards).

Meanwhile, the airport infrastructure is the number of paved airports per 1000 square kilometer of each country. The data of number of paved airport is obtained from CIA Factbook 2013 and 2014 while the land area is drawn from the World Bank's Indicator.

\section{Of the second stage}

- Export

$\mathrm{X}_{\mathrm{j}}$ is denoted as export of all textile products from Vietnam to country $\mathrm{j}$ in 2013 in million US dollars. The study includes the export data of Vietnam to 75 countries from UN Comtrade. The original database does not contain any 0 . 
- Income and Population

Data on GDP and population are sourced from the World Development Indicators (WDI), World Bank.

- Logistics

Logistics data is the quality of trade and transport-related infrastructure (1=low to 5=high), which is also taken from World Bank Database. Logistics performance index is constructed on a rating scale from 1 (very low) to 5 (very high).

\section{- Tariff}

Import tariff of partner's countries is taken from WITS (COMTRADE) database. It is generally assessed on the CIF value of the goods. Effectively applied tariff is the type of tariff levied on components, rather than finished products when the origin of a product is from more than one country.

- Real Exchange rate (RER)

RER is bilateral real exchange rate between Vietnam and country $\mathrm{j}$ in 2013, which is calculated as the product of the nominal exchange rate and relative price levels in each country. 
RESULTS

Finding and discussion

Table: Descriptive statistics

\begin{tabular}{|c|c|c|c|c|c|}
\hline Variable & $\mathbf{N}$ & Mean & SD & Min & Max \\
\hline $\mathrm{TC}$ & 274 & 418.2608 & 527.636 & 20 & 4095.2 \\
\hline Mode & 274 & 0.2627737 & 0.4409459 & 0 & 1 \\
\hline Distance & 274 & 7644.022 & 6284.715 & 403 & 20575 \\
\hline Days & 274 & 13.12774 & 11.07913 & 2 & 43.5 \\
\hline Infrastructure & 274 & 3.709752 & 2.237392 & 0.0193852 & 12.85714 \\
\hline Export & 262 & 210619.4 & 309231.4 & 23.229 & 975786.8 \\
\hline Income (Y) & 269 & $2.65 \mathrm{E}+12$ & $4.04 \mathrm{E}+12$ & $2.29 \mathrm{E}+09$ & $1.68 \mathrm{E}+13$ \\
\hline Pop & 274 & $3.00 \mathrm{E}+08$ & $4.78 \mathrm{E}+08$ & 284644 & $1.36 \mathrm{E}+09$ \\
\hline$\overline{\mathrm{RER}}$ & 236 & 0.0320832 & 0.0947285 & 0.0000227 & 0.3711004 \\
\hline Logistics & 272 & 3.326667 & .7921708 & 0 & 4.323295 \\
\hline Tariff & 258 & 6.372674 & 4.343892 & 0 & 20.1 \\
\hline TPP & 274 & 0.2153285 & 0.4118022 & 0 & 1 \\
\hline ASEAN & 274 & 0.2481752 & 0.4327444 & 0 & 1 \\
\hline Comcont & 274 & 0.5985401 & 0.4910906 & 0 & 1 \\
\hline
\end{tabular}

Source: Author's illustration 


\section{Determinants of transport cost}

We have tried several specifications, by testing for the significance of the explanatory variables. Since the interaction terms Infr*Mode and Dist*Mode may correlate with Dist, Infr and Mode variables, we run a multicollinearity test to see if there is any problem. A higher VIF (variance inflation factor) after the introduction of interaction terms is observed, however, $\mathrm{R}^{2}$ and the standard error of the equation do not change much. Therefore, we can safely ignore the multicollinearity problem with interaction terms.

The first analysis shows results which exclude the interaction terms (Infr*Mode and Distance*Mode). A number of conclusions were reached. First, the days coefficient has the expected positive sign, showing that a $1 \%$ increase in time to export increases transport costs in approximately $0.35 \%$ (Model 1 ).

The distance (from Cat Lai to destination ports) variable also has the expected positive coefficient, indicating that a higher distance is associated with higher transport costs. It is clear that distance has a strong impact on export (0.356), which is higher to those found in other studies of Hummels (1999) where distance coefficients range from 0.2-0.3 and Kumar and Hoffmann (2002) with a distance elasticity of 0.24 .

\section{Transport Costs and Export}

An improvement of $1 \%$ in the infrastructure of the destination country lowers transport costs by approximately $1.2 \%$, which is seven times higher than the magnitude of the port infrastructure coefficient in Marzinez et.al (2004) where the port infrastructure was captured for ship mode only. The infrastructure variable is likely to interact with the mode dummy when we consider the infrastructure of seaports and airports. As air shipping is much more costly than sea shipping, an improvement in airport infrastructure would not be sufficient to compensate for the higher prices that the traders have to pay.

The model is estimated for a sample of 207-216 observations with 2013 data. All the analyses explain 68 to 81 percent of the variations in direction of trade flows. We use the forecasted transport costs as an explanatory variable of textile export since the result from the Hausman (1978) test indicates that transport costs must be considered as endogenous in the import demand equation (IV estimation). Then, we compare the results with those obtained when using distance 
as a proxy for transport cost.

The analysis presents the OLS results for the baseline case, which excludes the distance, tariff and dummies. The coefficient on distance is negative signed and more significant than that of the forecasted transport costs. The standard variables are population, income, real exchange rate and logistics. As a fashionable product, apparel is quite sensitive to income $\left(Y_{j}\right)$. Wealthy and prosperous nations tend to pay more attention to their outlooks and seek for diversification in design, sophisticated tailor-made and materials from developing countries. They are willing to place an order to Vietnam factories as reasonable price coming from cheap labour source would offset transport and related costs.

Demographic variable (Pop) is statistically significant and positive in mode

(1). The more populous the countries are, the greater demands they have for apparels and clothes. In high income and sparsely populated nation, increase in population may indicate a rise in birth-rate and a growing demand for child wear. However, it is argued that higher population reduces income per capita and makes each individual poorer, reducing demand for imports.

Logistics variable is seen to be the strongest determinant of export. More specifically, a one-percentage rise in the importer's logistics index would raise Vietnam's export by nearly 3.8\%, ceteris paribus. This variable, however, gradually lose its magnitude and significance when we introduce other variables.

In the second analysis, we add the distance (Dist) variable and compare it with the forecasted transport cost (FTC) variable. The magnitude of distance indicates that a rise of $1 \%$ remoteness between two nations leads to a decrease in export of $0.99 \%$, which triples the $0.32 \%$ magnitude of forecasted transport cost.

Furthermore, tariff variable (Tariff) is added to include the non-tariff barriers towards trade flow. It is apparent that the magnitude of forecasted transport costs (0.303) is bigger than that of tariff (-0.176). However, it is quite interesting to see that once these dummy variables namely ASEAN, TPP and Comcont are included in the analysis, the impact of tariff turns out to be greater than that of transport cost. The implication is that the trade agreement lowers tariff and directly influences export through tariff channel.

The coefficient of the ASEAN variable $\left(\gamma_{8}\right)$ takes a negative sign and is 
statistically significant at the 1 percent level. Our results are quite similar to Nguyen (2010). It is apparent that ASEAN accounts for a smaller market share vis-à-vis non-ASEAN members in terms of gross domestic product and market size. The effect from ASEAN is quite marked, resulting in trade diversion of $0.7 \%$. The result indicate that Vietnam is more integrated into textile trades with non-ASEAN countries than that with ASEAN members.

The impact of TPP has not been not significant enough to be shown in statistics. A plausible explanation is that TPP has not been successful due to conflicting interests among its members. The proposal and implementation of TPP regulations still challenge Vietnamese textile exporters, especially the "yarnforward rule”. Moreover, apart from the US and Japan, potential customers of Vietnamese textiles are other TPP members such as, Chile, Peru and New Zealand.

Finally, the forecasted transport cost (FTC) is replaced by distance (Dist). The fitness of the equation is better with all the variables explain about $81 \%$ of the trade flow. A likely reason for this finding is that distance influences export value through channels other than freights and surcharges. For example, the costs to find information, translate languages and investigate culture are bound to add up trade costs.

\section{CONCLUSIONS AND IMPLICATIONS Conclusion}

It is a common belief that transport cost is decreasing and that international trade is not affected by freight rate as much, especially for light-weighted textile products. Our results from Vietnam's practice reveals that freight does not decrease from 2012 to 2014 and it possibly increases slightly, depending on the destinations. In addition to analysing freight rate, we take into account surcharges which increase or decrease unpredictably and unregulated by any law and regulation.

Another contribution of the research to the existing literature of Vietnam is that it takes into consideration the cost of transportation by air. We acknowledge that sea transportation is the most common mode in the survey sample (accounting for 70\%); however, there is a growing interest in air transport as well for the goods that are of high value, time and reliability.

Our results from the first estimations show that higher distance and poor 
partner port infrastructure leads to a notable increase in transport costs. Inclusion of time, mode and common continent variables improve the fit of the regression. Transporting a cargo by air is much more expensive than by ship. Also, lead time is considered money, so Vietnamese government should assist exporting enterprises by improving public infrastructure and simplify the existing customs clearance.

Our results from the second estimation show that higher importer income, depreciating real exchange rate and better logistics condition facilitate trade growth. In contrast, greater transport costs, distance and tariff significantly deter trade. In every case, distance is the best proxy for trade cost in the textile sector. Transport cost has larger impact than tariff only when free trade agreements are not included.

However, there are still some limitations in our study. First of all, since the freight rate in Vietnam is quite confidential within shipping lines, their agents and customers, we act as a typical cargo owner (customer of shipping lines). The freights and surcharges that the shipping lines informed us could be higher than the real market price, when shippers and ship owners have business relationship and trust each other. The paper also takes information from a sample of ship owners so there would exist the problem of selection bias and allocation concealment.

More crucially, the research ignores the inland transport costs, which might be a great issue in developing country such as Vietnam. We expect that further study on trade and transportation would cover the issue and bring more policy implications for the policy makers and the Vietnamese government.

\section{Implications}

- Improving sea port and airport infrastructure

The first implication to reduce ocean transport cost in Vietnam is to improve port infrastructure. According to Eric Johnson (2010), port and other infrastructure projects in Vietnam have been delayed significantly. In accordance with other studies such as Tae (2010), a proposed solution is that Vietnam should cooperate with domestic ports and foreign counterparts to improve port efficiency. This approach attracts foreign direct investment in port infrastructure, saves cost for the state budget and shares the risk with other entities. In addition, port services, especially at Cat Lai and Dinh Vu should be prioritized to optimize ship schedule plan, labour plan and inventory and warehouse plan. The infrastructure development is forecasted to bring about huger container volume across Vietnam's ports. 
Beside sea freight, a critical component of the air transport sector which needs improvement is airport infrastructure. Vietnam will need more investment in new terminals, longer runways and upgraded equipment to keep up with increases in air passenger traffic, which is estimated by the Civil Aviation Administration of Vietnam (CAAV) to increase 10 per cent-12 per cent a year during 2015-2020. The master plan envisages 26 airports in operation by 2020, including 10 international airports and 16 domestic airports. Foreign companies will be allowed to invest in the form of BOT. As no such project has yet been done in Vietnam, there are a myriad of technical details to be overcome before such a project comes to fruition.

\section{- $\quad$ Disclosing freight information}

Vietnam freight market was considered unfair competition and oligopolistic market. Auxiliary and unreasonable charges and freights have been in a sudden increase or decrease from shipping lines. The Ministry of Transportation should report Government statement on the matter and strengthen inspection and test regular shipping companies, seaports, finding the remedies to control charges, surcharges in amending the Vietnam Maritime Law to help promulgate and public the freight rate of any charges on maritime shipping companies which have business operations in Vietnam. Besides, our legislation should prohibit the practice of unreasonable charges which do not in accordant to international practice.

- $\quad$ Reducing lead time in textile industry

As discussion above, it is clearly seen that time is an important component of trade and in turn, affects the competitiveness of textile products. As in the future, there would not be the competitions between companies but between their supply chains. An average for the lead time of production and delivery of textile is 60-70 days, in comparison with only 50-60 days in China, Malaysia and Thailand. One way to shorten lead time is to improve logistics from procurement, operation to delivery and sales to customers.

\section{- $\quad$ Promoting Free Trade Agreements to lower tariff}

Regarding the effects of Free Trade Agreement (FTA) on intra-industry trade in the case of Textile Sector in Vietnam, it is found that bilateral and regional FTAs bring the opportunities for Vietnam to eliminate tariff and non-tariff barriers to trade 
and investment among member countries.

It is proposed that Vietnam should prepare for the formation and enforcement FTAs to enjoy greater benefits. Developing sub-supporting industries becomes important issues and urgent decisions to raise competitiveness of textile industry. As many companies have proposed, the government should establish an industrial cluster to concentrate manufacturing factories near the sources of raw materials. Besides, waste water from dyeing and washing process and other removals from cutting, sewing and button filling which may pollute the environment should be treated well through legal requirements and check-ups. According to economic experts, following FTAs, there would be more and more FDI and ODI pouring into developing countries such as Vietnam in the upcoming years and the government should take these advantages to call for investments into waste treatment processes and advanced technologies to improve efficiency while reducing the impact to the environment.

\section{REFERENCES}

1. Hummels, D, Ishii, Jand Yi, K.M., 2001. The nature and growth of vertical specialization in world trade, Journal of International Economics, 54, 75-96

2. Hummels, D., 1999. Towards a geography of trade costs, Mimeo, University of Chicago: Chicago.

3. Hummels, D., 2001. Have international transportation costs declined? Mimeo, Chicago.

4. Limao, $\mathrm{N}$ and Venables, AJ.2001. Infrastructure, geographical disadvantage and transport costs. World Bank Economic Review 15:451-479.

5. Martínez-Zarzoso, I., \& Suárez-Burguet, C., 2005. Transport costs and trade: empirical evidence for Latin American imports from the European Union. Journal of International Trade \& Economic Development, 14(3), 353-371.

6. Martínez-Zarzoso, I., García-Menéndez, L., \& Suárez-Burguet, C., 2003. Impact of transport costs on international trade: the case of Spanish ceramic exports. Maritime Economics \& Logistics, 5(2), 179-198.

7. Martínez-Zarzoso, I., Pérez-García, E. M., \&Suárez-Burguet, C., 2008. Do transport costs have a differential effect on trade at the sectoral level?. Applied Economics, 40(24), 3145-3157.

8. Tinbergen, J., 1962. Shaping the world economy; suggestions for an international economic policy.

9. American Shipping Logistics, 2013. Bảng cước hàng không. [Online]. 
Available at: http://asl-corp.com/vi/tien-ich/bang-gia/144/gia-cuoc-hangkhong [Assessed 13 April 2014].

10. CEPII, 2014. Geography. [online] Available at:

http://www.cepii.fr/cepii/en/bdd modele/bdd.asp [Accessed 2 March 2014] 11. CIA, 2014. The World Factbook. [online] Available at:

https://www.cia.gov/library/publications/the-world-factbook/geos/vm.html.

[Accessed 2 March 2014] 